\title{
THE EFFECT OF DIFFERENT CULTIVATION METHODS ON RICE GROWTH AND DEVELOPMENT
}

\author{
HU, L. ${ }^{1,2 \#}-$ DU, P. ${ }^{1,2 \#}-$ LUO, H. W. ${ }^{1,3 \#}-$ CHENG, S. R. ${ }^{1,3}-$ WU, T. Y. ${ }^{1}-$ HE, J. ${ }^{1,2}-$ LIU, Y. F. ${ }^{1}-$ \\ MenG, S. B. ${ }^{1,2}-$ ChEN, B. Y. ${ }^{1,2}-$ WANG, Z. M. ${ }^{1,2}-$ TANG, X. R. ${ }^{1,3 *}$

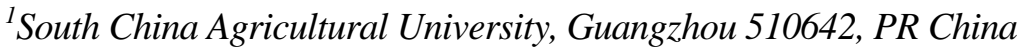 \\ ${ }^{2}$ Key Laboratory of Key Technology for South Agricultural Machine and Equipment \\ Ministry of Education, Guangzhou 510642, PR China \\ ${ }^{3}$ Department of Crop Science and Technology, College of Agriculture \\ South China Agricultural University, Guangzhou 510642, PR China \\ ${ }^{\#}$ These authors have contributed equally to this work. \\ *Corresponding author \\ e-mail:tangxr@scau.edu.cn \\ (Received 23 $3^{\text {rd }}$ Jan 2019; accepted $18^{\text {th }}$ Feb 2019)
}

\begin{abstract}
Cultivation is an important part in rice production which could affect rice growth and development significantly. In order to study the effect of different cultivation methods on rice performance, two land preparation ways (plough and rotary) and two rice growing techniques (direct-seed and transplanted rice) were used in present study and four cultivation methods were set as: (PD) the land was puddle twice with plough cultivator and pre-germinated seeds were hill-seeded with direct seeding machine; (RD) the land was puddle twice with rotary cultivator and pre-germinated seeds were hillseeded with direct seeding machine; (PT) the land was puddle twice with plough cultivator and 15-dayold seedlings were hill-transplanted with transplant machine; (RT) the land was puddle twice with rotary cultivator and 15-day-old seedlings were hill-transplanted with transplant machine. The results showed that the highest yield was recorded in both PT and RT and the lowest yield was recorded in RD. There was no difference among different cultivation methods on net photosynthetic rate but different cultivation affected the transpiration rate and water use efficiency at different stage differently. Furthermore, the highest head rice rate and grain protein and the lowest chalky rice rate was all recorded in PD treatment. Overall, higher yield was recorded in transplanted rice cultivation than direct-seed cultivation and the greatest grain quality was observed under direct seeding rice cultivation and plough tillage conditions.
\end{abstract}

Keywords: rice, tillage, cultivation methods, photosynthesis, yield, grain quality

\section{Introduction}

Rice (Oryza sativa. L) is one of the main crops in Asia and the rice production system has become the backbone of Chinese food security system for many years (Xing et al., 2019; Wang et al., 2019). In 2017, China's rice planting area was 6.795 billion hectares (Han et al., 2019). However, the availability of arable land has been decreased in recent years and the increasing population has intensified the conflict for land planning between fiber and cereal crops (Fang et al., 2019). Therefore, experts are inevitably striving to find more ways to improve crop productivity.

Normally, land preparation is an important part in rice production because puddling is required to decrease the loss of water and nutrients through excessive percolation and it also is able to reduce weeds and enhance nutrient availability (Hazra et al., 2014; Alam et al., 2018). Previous studies already showed that soil puddling in paddy field benefits rice yield (Datta and Kerim, 1974; Kukal and Aggarwal, 2003). However, the 
effect of puddling is still not clear regarding rice growth and development despite the benefits.

Normally, mechanical puddling is performed twice in Chinese paddy field, ploughing and rotary tillage. There also are two rice system which including direct seeding rice and transplanted-flooded rice in China. Those managements all had their own impacts on rice growth and development. For example, the study of Pan et al. (2017) indicated that direct seeding rice could be a more substitutive rice growing technique to transplanted-flooded rice with less production costs, labor and extra efforts for nursery raising, seedling uprooting, and transplanting. SUN (2017) demonstrated that ploughing tillage could help to improve the soil temperature, improve the environment of soil and promote the root activity and improve the production of tobacco leaf. But there was no much report about the effect of different puddling or growing technique on rice growth, development, yield and quality.

Thus, in order to study the effect of different cultivation methods on rice growth and development, present study was conducted in Guangdong Province, China with two mechanical puddling and two rice growing techniques.

\section{Material and Methods}

\section{Plant materials and growing conditions}

A fragrant rice cultivar, Meixiangzhan-2, which having a growth period of 111-114 days and widely planted in South China, was used in the experiment and planted at late season of 2017 in Zengcheng $\left(23^{\circ} 13^{\prime} \mathrm{N}, 113^{\circ} 81^{\prime}\right.$ E, altitude $11 \mathrm{~m}$ ), Guangdong. The experimental site enjoyed a subtropical monsoon climate with mean annual air temperatures of $21.3^{\circ} \mathrm{C}$ and mean annual precipitation of $2660.9 \mathrm{~mm}$. Before sowing, the seeds were soaked in water for $24 \mathrm{~h}$, germinated in manual climatic boxes for another $12 \mathrm{~h}$ and shade-dried. Some of the germinated seeds were sown in polyvinyl chloride trays for nursery raising. The experimental soil in Zengcheng was sandy loam containing organic matter $10.04 \mathrm{~g} \mathrm{~kg}^{-1}$, total $\mathrm{N} 0.50 \mathrm{~g} \mathrm{~kg}^{-1}$, total $\mathrm{P} 0.26 \mathrm{~g} \mathrm{~kg}^{-1}$, and total $\mathrm{K} 15.10 \mathrm{~g} \mathrm{~kg}^{-1}$.

\section{Treatment description and plant sampling}

Two land preparations, ploughing $(\mathrm{P})$ and $\operatorname{rotary}(\mathrm{R})$ were adopted with two growing techniques. The treatment description is as below:

- PD: Before planting, the land was puddle twice with plough cultivator. Pregerminated seeds were hill-seeded with direct seeding machine at a space of $25 \times 15 \mathrm{~cm}$ while each hill was planted with $4-6$ seeds.

- RD: Before planting, the land was puddle twice with rotary cultivator. Pregerminated seeds were hill-seeded with direct seeding machine at a space of $25 \times 15 \mathrm{~cm}$ while each hill was planted with 4-6 seeds.

- PT: Before planting, the land was puddle twice with plough cultivator. 15-day-old seedlings were hill-transplanted with transplant machine at a space of $25 \times 15 \mathrm{~cm}$ while each hill was transplanted with 4-6 seedlings.

- RT: Before planting, the land was puddle twice with rotary cultivator. 15-day-old seedlings were hill-transplanted with transplant machine at a space of $25 \times 15 \mathrm{~cm}$ while each hill was transplanted with 4-6 seedlings. 
The treatments were arranged in randomized complete block design (RCBD) in triplicate in each year with net plot size of $120 \mathrm{~m}^{2}$. At tillering stage, heading stage and maturity, ten random rice plants were collected from each plot, for estimation of dry matter accumulation.

\section{Photosynthesis}

Portable photosynthesis system (CIRAS 2; PP systems, Amesbury, MA, USA) was used to determine net photosynthetic rate and gas exchange attribute i.e., stomatal conductance, intercellular carbon dioxide concentration, transpiration rate, water use efficiency and vapor pressure deficit at 09:00-10:30 a.m.

\section{Grain quality}

After sun drying, grains were stored at room temperature for at least a month to determine grain quality components. About $1.0 \mathrm{~kg}$ rice grains from each treatment was taken from storage and brown rice rate was estimated using a rice huller (Jiangsu, China) while milled rice and head rice recovery rates were calculated by using a Jingmi testing rice grader (Zhejiang, China). Grains with chalkiness and chalkiness degree were estimated by using an SDE-A light box (Guangzhou, China) while an Infratec-1241 grain analyzer (FOSS-TECATOR) was used to determine the grain amylose and protein contents.

\section{Yield and yield related traits}

At maturity stage, the rice grains were harvested from seven-unit sampling area $\left(1 \mathrm{~m}^{2}\right)$ in each plot and then threshed by machine. The harvested grains were sun-dried and weighted in order to determinate the grain yield. Twenty hills of rice from different locations in each plot were sampled for estimate the average effective panicles number per hill. Then, eight hills representative plants were taken for estimation of the yield related traits.

\section{Statistical analysis}

Data were analyzed on Statistix 8.1 (Analytical Software, Tallahassee, FL, USA) while differences among means were separated by using least significant difference (LSD) test at 5\% probability level. Graphical representation was conducted via Sigma Plot 14.0 (Systat Software Inc., California, USA).

\section{Result}

\section{Yield and yield related trails}

As shown in Table 1, different cultivation methods affected rice yield and its related trails significantly. The highest yield was recorded in both PT and RT while there was no significant difference between RT and PT. The lowest yield was recorded in RD. The difference in rice yield among different cultivation could be explained by the yield related trails. For panicle number, the panicle number per hill in RT and PT was significantly higher than PD and RD; For grains number per panicle, the highest grains number was recorded in PD and grains number in RD and PT was remarkably number 
than PD; For seed-setting rate, the highest rate was recorded in PT; For grain weight, the 1000-grain weight in PD was significantly higher than RD, PT and RT.

Table 1. The effect of different cultivation methods on rice yield and its related trails

\begin{tabular}{c|c|c|c|c|c}
\hline Treatment & $\begin{array}{c}\text { Panicle number } \\
\text { per hill }\end{array}$ & $\begin{array}{c}\text { Grains number } \\
\text { per panicle }\end{array}$ & $\begin{array}{c}\text { Seed-setting } \\
\text { rate (\%) }\end{array}$ & $\begin{array}{c}\text { 1000-grain } \\
\text { weight (g) }\end{array}$ & Yield $\left(\mathbf{t ~ h a}^{-2}\right)$ \\
\hline PD & $328.74 \pm 2.37 \mathrm{~b}$ & $117.87 \pm 4.22 \mathrm{a}$ & $74.29 \pm 1.77 \mathrm{~b}$ & $22.08 \pm 0.31 \mathrm{a}$ & $6.63 \pm 0.14 \mathrm{~b}$ \\
RD & $329.38 \pm 1.01 \mathrm{~b}$ & $107.33 \pm 4.15 \mathrm{~b}$ & $74.05 \pm 4.15 \mathrm{~b}$ & $20.74 \pm 0.27 \mathrm{~b}$ & $5.61 \pm 0.38 \mathrm{c}$ \\
PT & $385.06 \pm 4.65 \mathrm{a}$ & $106.80 \pm 6.99 \mathrm{~b}$ & $82.41 \pm 6.99 \mathrm{a}$ & $20.84 \pm 0.05 \mathrm{~b}$ & $7.11 \pm 0.29 \mathrm{ab}$ \\
RT & $395.73 \pm 18.51 \mathrm{a}$ & $111.87 \pm 3.25 \mathrm{ab}$ & $77.77 \pm 3.23 \mathrm{ab}$ & $21.16 \pm 0.28 \mathrm{~b}$ & $7.43 \pm 0.29 \mathrm{a}$ \\
\hline
\end{tabular}

Values sharing a common letter within a column don't differ significantly at $(\mathrm{P} \leq 0.05)$ according to least significant difference (LSD) test for both the years. The same as below

\section{Grain quality}

As shown in Table 2, different cultivation methods affected grain quality significantly. There was no remarkable difference among different cultivation methods in both brown rice rate and milled rice rate. However, the head rice rate in PD and RD was significantly higher than PT and RT. The moisture in PD and RD was significantly higher than PT and RT. The trend of crude protein content was recorded as: PD > RD > RT > PT. The lowest amylose content was recorded in RT while there was no significant difference among PD, RD and PT. Moreover, there was no remarkable difference among Akali and chalkiness whilst the trend of chalky rice rate was recorded as: RT $>$ PT $>$ RD $=$ PD.

Table 2. The effect of different cultivation methods on grain quality

\begin{tabular}{c|c|c|c|c|c|c|c|c|c}
\hline Treatment & $\begin{array}{c}\text { Brown rice } \\
\text { rate }(\%)\end{array}$ & $\begin{array}{c}\text { Milled rice } \\
\text { rate }(\%)\end{array}$ & $\begin{array}{c}\text { Head rice } \\
\text { rate }(\%)\end{array}$ & $\begin{array}{c}\text { Moisture } \\
(\%)\end{array}$ & $\begin{array}{c}\text { Crude } \\
\text { protein } \\
\text { content }(\%)\end{array}$ & $\begin{array}{c}\text { Amylose } \\
\text { content }(\%)\end{array}$ & Akali & $\begin{array}{c}\text { Chalky rice } \\
\text { rate }(\%)\end{array}$ & $\begin{array}{c}\text { Chalkiness } \\
(\%)\end{array}$ \\
\hline PD & $77.12 \pm 0.87 \mathrm{a} 69.86 \pm 0.29 \mathrm{a}$ & $33.39 \pm 0.87 \mathrm{a}$ & $12.90 \pm 0.01 \mathrm{a}$ & $8.87 \pm 0.07 \mathrm{a}$ & $17.63 \pm 0.09 \mathrm{a}$ & $6.37 \pm 0.03 \mathrm{a}$ & $8.33 \pm 1.20 \mathrm{c}$ & $14.17 \pm 1.17 \mathrm{a}$ \\
$\mathrm{RD}$ & $77.50 \pm 0.28 \mathrm{a}$ & $70.33 \pm 0.41 \mathrm{a}$ & $36.45 \pm 0.45 \mathrm{a}$ & $12.67 \pm 0.03 \mathrm{~b}$ & $8.50 \pm 0.01 \mathrm{~b}$ & $17.80 \pm 0.06 \mathrm{a}$ & $6.47 \pm 0.09 \mathrm{a}$ & $7.33 \pm 1.45 \mathrm{c}$ & $11.33 \pm 0.88 \mathrm{a}$ \\
$\mathrm{PT}$ & $78.20 \pm 0.22 \mathrm{a}$ & $70.38 \pm 0.74 \mathrm{a}$ & $24.21 \pm 1.21 \mathrm{~b}$ & $12.97 \pm 0.03 \mathrm{a}$ & $7.87 \pm 0.07 \mathrm{~d}$ & $17.73 \pm 0.09 \mathrm{a}$ & $6.30 \pm 0.01 \mathrm{a}$ & $18.00 \pm 0.58 \mathrm{~b}$ & $13.00 \pm 1.32 \mathrm{a}$ \\
$\mathrm{RT}$ & $77.50 \pm 0.41 \mathrm{a} 70.19 \pm 0.21 \mathrm{a}$ & $22.60 \pm 0.51 \mathrm{~b}$ & $12.77 \pm 0.07 \mathrm{~b}$ & $8.10 \pm 0.01 \mathrm{c}$ & $17.17 \pm 0.09 \mathrm{~b}$ & $6.37 \pm 0.03 \mathrm{a}$ & $24.67 \pm 3.18 \mathrm{a}$ & $10.67 \pm 1.09 \mathrm{a}$ \\
\hline
\end{tabular}

\section{Plant height}

As shown in Figure 1, the plant height of rice under different cultivation methods increased with the growth until 70 days after the sowing and then it gradually stabilized and remained unchanged. The trend of plant height was recorded as: PT $=\mathrm{RT}>\mathrm{PD}>$ RD since 42 days after the sowing.

\section{Photosynthesis and gas exchange}

As shown in Figure 2, there was no remarkable difference in net photosynthetic rate among different cultivation methods at tillering stage, heading stage and maturity. Similar conditions were also observed in both intercellular carbon dioxide concentration and stomatal conductance. However, at tillering stage, the transpiration rate in RT was 
significantly higher than PD while the both the lowest vapor pressure deficit and water use efficiency were recorded in RT. Moreover, at maturity, both the highest transpiration rate and the lowest vapor pressure deficit were recorded in RD treatment.

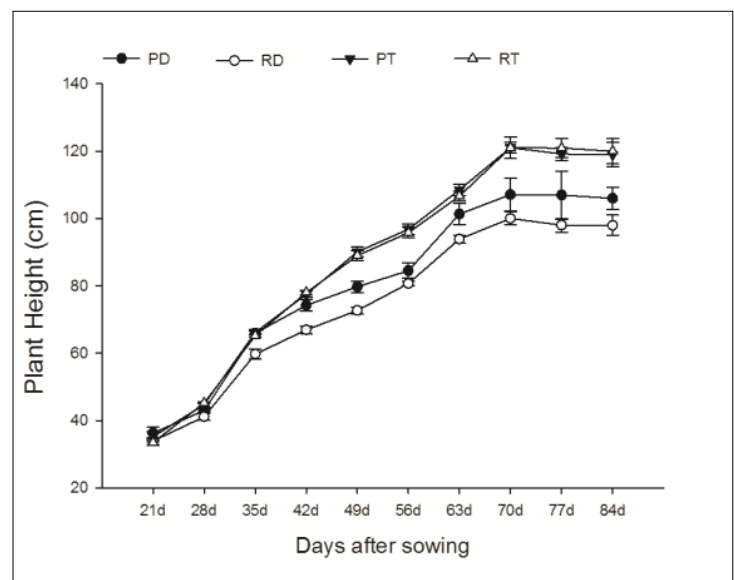

Figure 1. The effect of different cultivation methods on rice plant height

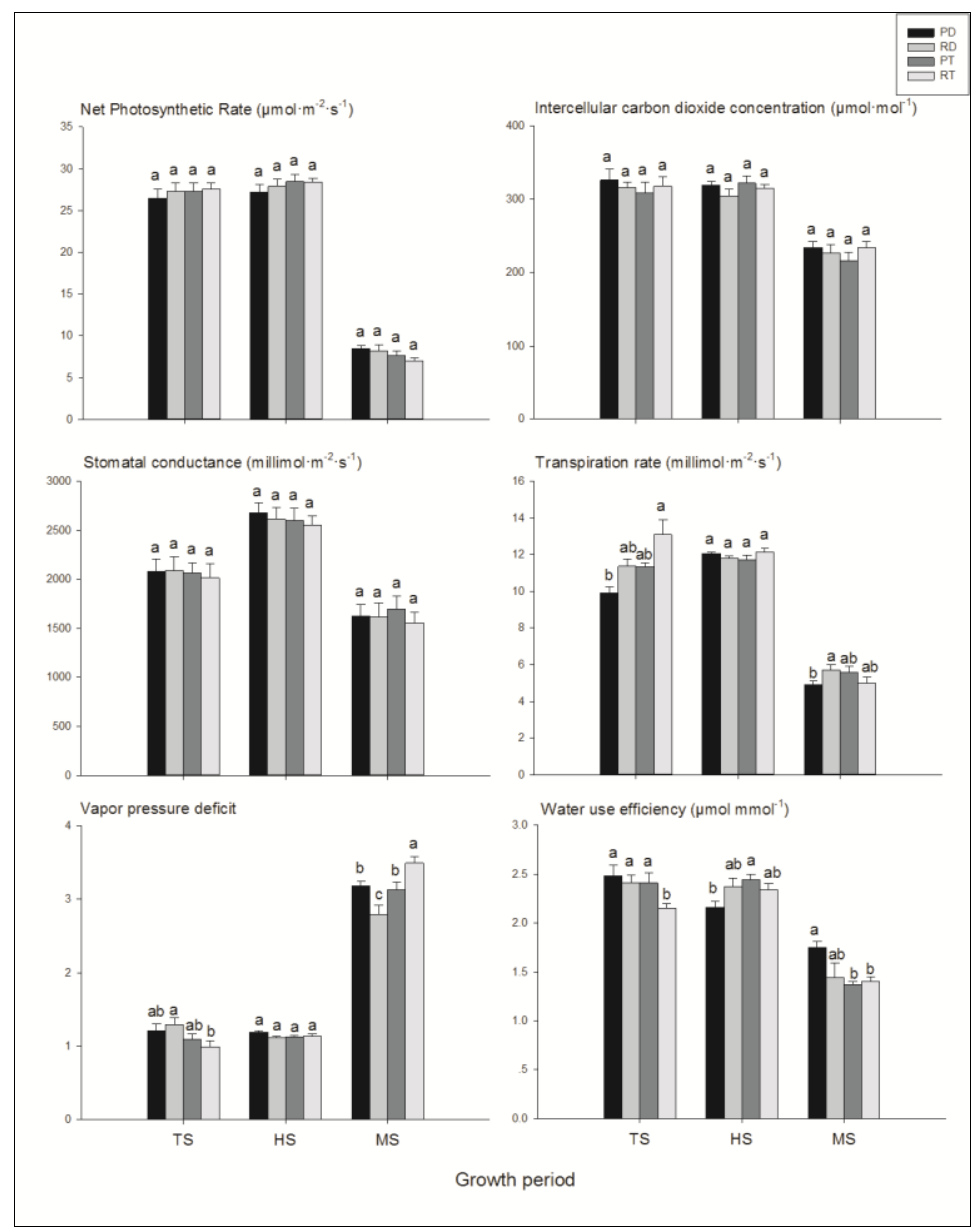

Figure 2. The effect of different cultivation methods on rice photosynthesis and gas exchange. Means sharing a common letter don't differ significantly at $(P \leq 0.05)$ according to least significant difference ( $L S D)$ test 


\section{Dry matter accumulation}

Different cultivation methods affected dry matter weight differently (Figure 3). At heading stage, the dry matter weight in PT and RT were significantly higher than PD and RD. At maturity, the trend of dry matter weight was recorded as: PT $=\mathrm{RT}>\mathrm{PD}>$ RD.

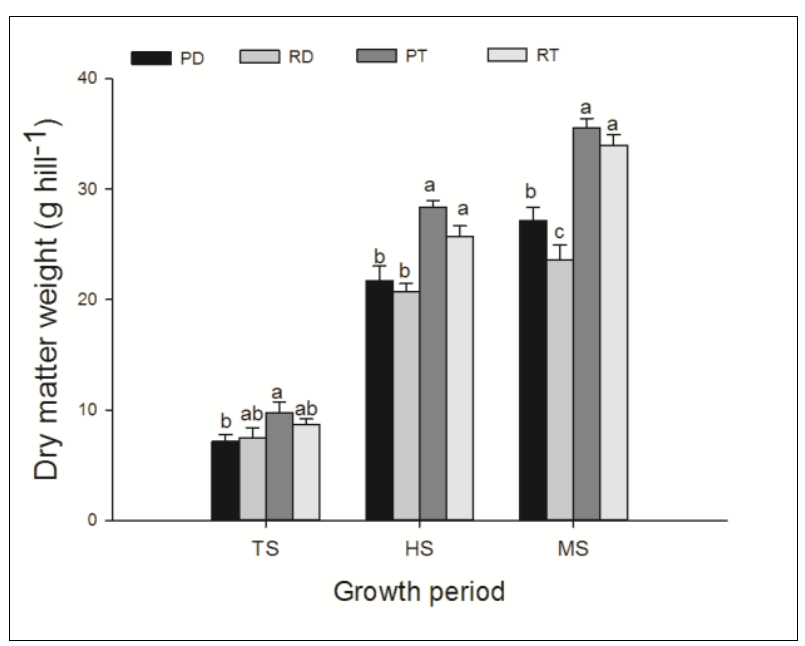

Figure 3. The effect of different cultivation methods on dry matter accumulation of rice

\section{Discussion}

Cultivation is a very important part in rice production. Some researchers already investigated the effects of some cultivation methods on rice performance and paddy fields. For example, Zhang et al. (2008) indicated that non-flooded mulching cultivation not only could increase root oxidation activity and photosynthesis, but also enhanced the activities of key enzymes in sucrose-to-starch conversion at filling stage. The study of Bouwman (1991) revealed that different cultivation methods could affect the methane emissions in paddy field by influencing the oxido-reduction capacity of the soil. Moreover, the study of Qin et al. (2006) showed that non-flooded rice cultivation was able to mediate rice growth, decrease the evapotranspiration and increase water use efficiency. In our study, there were also some differences among different cultivation methods in rice yield and yield related trails. The highest yield was recorded in both PT and RT while the rice yield in PT was significantly higher than PD just like RT was higher than RD. This discovery indicated that the transplanted-flooded rice cultivation had higher yield compared to direct seeding rice. The increment of yield in transplantedflooded rice cultivation could be explained by the higher panicle number and seedsetting rate. The further reason might be the transplanted rice cultivation had the nursery raising part for seedling growth which direct seeding rice culitivation didn't. This result was consistant with previous studies which showed that nursery practice was benefit to early establishment for rice and could improve the rice yield protential (Sarangi et al., 2015; Zhang et al., 2017). Moreover, there was no signifcant difference in yield between PT and RT whilst the grain number, grain weight and yield in PD were signifcantly higher than RD. This discovery might indicated that the land prepation of plough tillage would be more suitable for direct seeding rice system. 
Present study also showed that different cultivation methods also affected the grain quality significantly. Compared to PT and RT, PD and RD had higher head rice rates and crude protein contents. The lower chalky rice rates were also recorded in PD and RD than PT and RT. Grain quality is the main factor which depends the rice price in market (Ahmad et al., 2017; Norton et al., 2017). In our study, the result showed that the grain quality in direct seeding rice was higher than transplanted-flooded rice. Moreover, the highest grain protein content was recorded in PD and it might indicate that the environment of direct seeding rice cultivation and plough tillage would be the most suitable for protein content biosynthesis in grains. The reasons could be PD condition enhanced the activity of key enzymes involved in protein biosynthesis or improved the nitrogen absorption, utilization and transportation in rice (TsukaguchiNitta and Matsuno, 2016; Luo et al., 2018; Wang et al., 2018).

In our study, there was no significant difference among different cultivation methods in net photosynthetic rate. But interestingly, we found that different cultivation methods could alter the vapor pressure deficit in paddy field by affecting the transpiration rate of rice. The values of water use efficiency were also different under different cultivation methods. Those differences might be caused by plant-soil systems which were different because of the different land preparations and rice growing techniques (Pan et al., 2017; Wang et al., 2017).

\section{Conclusion}

Different cultivation methods affected rice yield and quality differently. Present study showed that the higher yield was recorded in transplanted rice cultivation than directseed cultivation and the greatest grain quality was observed under direct seeding rice cultivation and plough tillage conditions. In order to reveal the mechanism of how cultivation affected rice performance, more investigation should be couducted at the field trials or at molecular level before the real application.

Acknowledgements. This study was supported by the National Key Research and Development Program of China (2016YFD0700301), National Natural Science Foundation of China (31601225), Science and Technology Planning Project of Guangzhou, China (No. 201610010071), Science and Technology Planning Project of Yunfu, China (201702-2) and Special Funds for Scientific and Technological Innovation and Cultivation of University Students Guangdong (pdjh2019a0075).

\section{REFERENCES}

[1] Ahmad, U., Alfaro, L., Yeboah-Awudzi, M., Kyereh, E., Dzandu, B., Bonilla, F., Chouljenko, A., Sathivel, S. (2017): Influence of milling intensity and storage temperature on the quality of Catahoula rice (Oryza sativa L.). - LWT - Food Science and Technology 75: 386-392.

[2] Alam, M. J., Humphreys, E., Sarkar, M. A. R., Sudhir-Yadav (2018): Comparison of dry seeded and puddled transplanted rainy season rice on the High Ganges River Floodplain of Bangladesh. - European Journal of Agronomy 96: 120-130.

[3] Bouwman, A. F. (1991): Agronomic aspects of wetland rice cultivation and associated methane emissions. - Biogeochemistry 15: 65-88.

[4] Datta, S. K. D., Kerim, M. S. A. A. (1974): Water and Nitrogen Economy of Rainfed Rice as Affected by Soil Puddling1. - Soil Science Society of America Journal 38: 515518. 
[5] Fang, S., Gao, K., Hu, W., Wang, S., Chen, B., Zhou, Z. (2019): Foliar and seed application of plant growth regulators affects cotton yield by altering leaf physiology and floral bud carbohydrate accumulation. - Field Crops Research 231: 105-114.

[6] Han, H., Cui, Y., Huang, Y., Wang, S., Duan, Q., Zhang, L. (2019): Impacts of the channel/barrier effect and three-dimensional climate-A case study of rice water requirement and irrigation quota in Yunnan, China. - Agricultural Water Management 212: 317-327.

[7] Hazra, K. K., Venkatesh, M. S., Ghosh, P. K., Ganeshamurthy, A. N., Kumar, N., Nadarajan, N., Singh, A. B. (2014): Long-term effect of pulse crops inclusion on soilplant nutrient dynamics in puddled rice (Oryza sativa L.)-wheat (Triticum aestivum L.) cropping system on an Inceptisol of Indo-Gangetic plain zone of India. - Nutrient Cycling in Agroecosystems 100: 95-110.

[8] Kukal, S. S., Aggarwal, G. C. (2003): Puddling depth and intensity effects in rice-wheat system on a sandy loam soil: I. Development of subsurface compaction. - Soil \& Tillage Research 72: 1-8.

[9] Luo, H. W., Wang, Z. M., Chen, Y. Y., Zheng, A. X., Chen, Y. L., Du, P., Mao, T., Meng, S. B, Tang, X. R. (2018): THE EFFECTS OF DIFFERENT TEMPERATURES ON THE BIOSYNTHESIS OF GRAIN PROTEIN IN RICE AT FILLING STAGE. - Applied Ecology and Environmental Research 16: 8017-8027.

[10] Norton, G. J., Shafaei, M., Travis, A. J., Deacon, C. M., Danku, J., Pond, D., Cochrane, N., Lockhart, K., Salt, D., Hao, Z. (2017): Impact of alternate wetting and drying on rice physiology, grain production, and grain quality. - Field Crops Research 205: 1-13.

[11] Pan, J., Liu, Y., Zhong, X., Lampayan, R. M., Singleton, G. R., Huang, N., Liang, K., Peng, B., Tian, K. (2017): Grain yield, water productivity and nitrogen use efficiency of rice under different water management and fertilizer-N inputs in South China. Agricultural Water Management 184: 191-200.

[12] Pan, S., Wen, X., Wang, Z., Ashraf, U., Tian, H., Duan, M., Mo, Z., Fan, P., Tang, X. (2017): Benefits of mechanized deep placement of nitrogen fertilizer in direct seeding rice in South China. - Field Crops Research 203: 139-149.

[13] Qin, J., Feng, H. U., Zhang, B., Wei, Z., Huixin, L. I. (2006): Role of straw mulching in non-continuously flooded rice cultivation. - Agricultural Water Management 83: 252-260.

[14] Sarangi, S. K., Maji, B., Singh, S., Burman, D., Mandal, S., Sharma, D. K., Singh, U. S., Ismail, A. M., Haefele, S. M. (2015): Improved nursery management further enhances the productivity of stress-tolerant rice varieties in coastal rainfed lowlands. - Field Crops Research 174: 61-70.

[15] SUN Jingguo, W. C. C. Z. (2017): The influence of different tillage on soil and flue-cured tobacco. - Journal of Hubei University (Natural Science) 39: 299-304.

[16] Tsukaguchi, T., Nitta, S., Matsuno, Y. (2016): Cultivar differences in the grain protein accumulation ability in rice (Oryza sativa L.). - Field Crops Research 192: 110-117.

[17] Wang, Y., Zhou, L., Jia, Q., Yu, W. (2017): Water use efficiency of a rice paddy field in Liaohe Delta, Northeast China. - Agricultural Water Management 187: 222-231.

[18] Wang, Q., Nian, J., Xie, X., Yu, H., Zhang, J., Bai, J., Dong, G., Hu, J., Bai, B., Chen, L. (2018): Genetic variations inARE1mediate grain yield by modulating nitrogen utilization in rice. - Nature Communications 9: 735.

[19] Wang, Y., Dang, F., Zheng, X., Zhong, H. (2019): Biochar amendment to further reduce methylmercury accumulation in rice grown in selenium-amended paddy soil. - Journal of hazardous materials 365: 590-596.

[20] Xing, Y., Wang, J., Xia, J., Liu, Z., Zhang, Y., Du, Y., Wei, W. (2019): A pilot study on using biochars as sustainable amendments to inhibit rice uptake of $\mathrm{Hg}$ from a historically polluted soil in a Karst region of China. - Ecotoxicology and environmental safety 170: $18-24$. 
[21] Zhang, Z., Zhang, S., Yang, J., Zhang, J. (2008): Yield, grain quality and water use efficiency of rice under non-flooded mulching cultivation. - Field Crops Research 108: 71-81.

[22] Zhang, Z., Huang, F., Shao, C. H., Chen, H., Lin, W. (2017): Differential proteomic analysis of rice seedlings reveals the advantage of dry-raising nursery practices. - Plant Growth Regulation 84: 1-13.

\section{APPENDIX}

\section{Photos of the experiment}

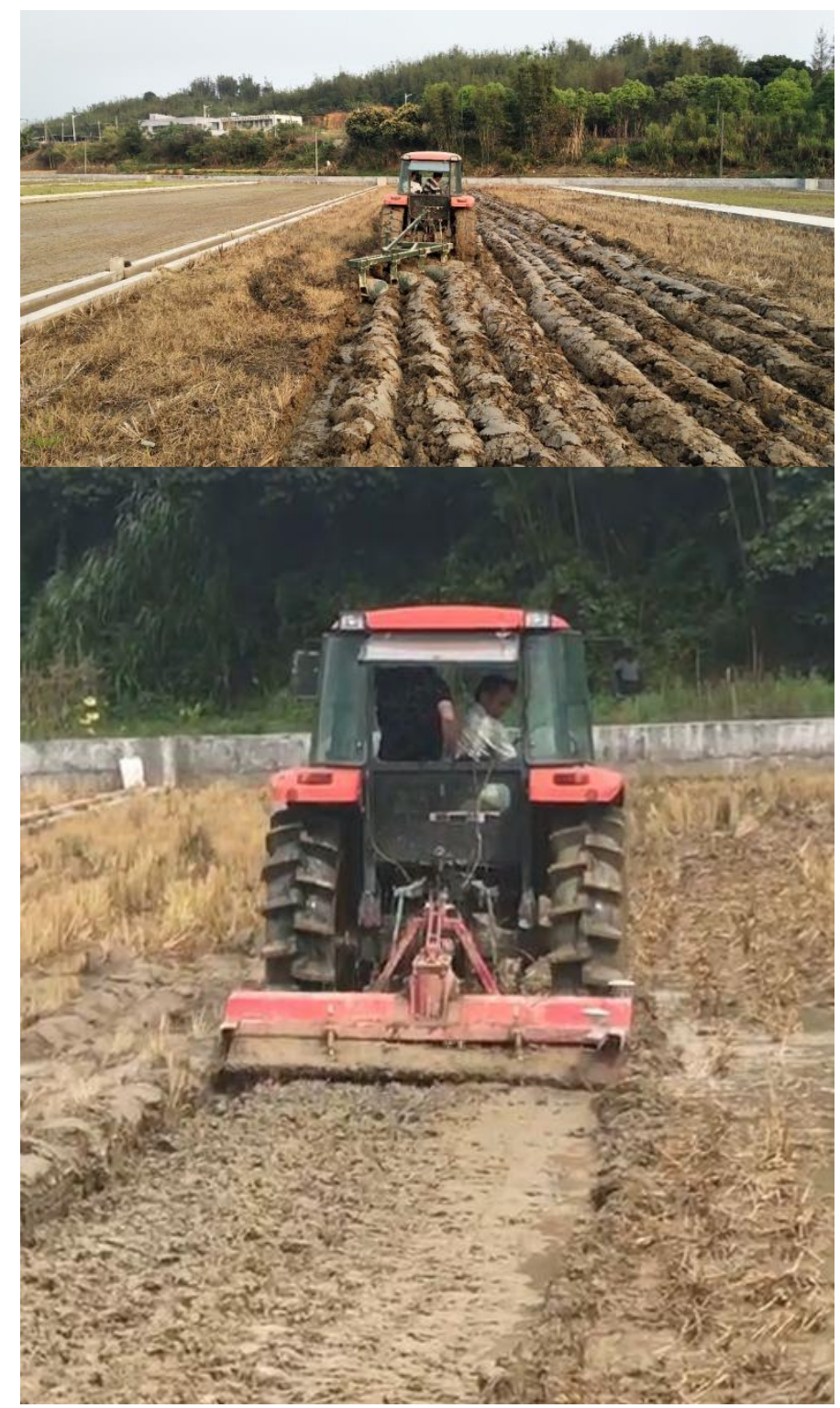

APPLIED ECOLOGY AND ENVIRONMENTAL RESEARCH 17(2):3867-3875 http://www.aloki.hu • ISSN 15891623 (Print) • ISSN 17850037 (Online) DOI: http://dx.doi.org/10.15666/aeer/1702_38673875 (C) 2019, ALÖKI Kft., Budapest, Hungary 